\title{
Kegagalan Gerakan Buruh dan Partai Buruh Pada Pemilu Era Reformasi \\ The Failure of the Labor Movement And Labor Party in the Reform Era General Election
}

\section{Dodi Faedlulloh}

Ilmu Administrasi Negara, Universitas Lampung

email: dodifaedlulloh@gmail.com

\section{Riwayat Artikel}

Diterima 4 Juli 2019

Direvisi 13 September 2019

Disetujui 7 Oktober 2019

doi: https://doi.org/10.22212/ jp.v10i1.1448

\begin{abstract}
This article explains about the labor movement as an agenda of its organization (labor party) to pursue labor's aspirations which have been rarely accommodated by government. A possible strategy that can be devised by the labor movement to establish a political party is by developing a strong constituency. This can be achieved by accommodating discussions on important issues from the grassroot level to identify problems and solutions as a form of political education for both labors and the public in general. Moreover, the labor movement needs to promote coordination and avoid inter-organizational disharmony and division. All labor practitioners shall work together and share ideas to shape a committed vision towards establishment of the labor party. Another vital part of this agenda lies in the importance of the implementation of general elections that facilitates the movement of alternative parties. Therefore, current formal administrative rules that hinder the registration of new political parties need to be urgently revised to promote better democracy in Indonesia.

Keywords: Labor; Labor Party; Election.
\end{abstract}

\begin{abstract}
Abstrak
Artikel ini membahas tentang gerakan buruh dalam agenda membangun partainya sendiri untuk memperjuangkan aspirasi-aspirasi buruh yang selama ini tidak diakomodasi. Strategi yang bisa dilakukan oleh gerakan buruh untuk membuka kemungkinan membentuk partai politik yaitu dengan membangun konstituen yang kuat dengan cara melaksanakan penyerapan aspirasi dari bawah dalam mengidentifikasi masalah beserta tawaran solusi sebagai bentuk dari pendidikan politik bagi rakyat dan buruh. Selain itu, untuk mengurangi fragmentasi antar lintas organisasi, gerakan buruh juga harus segera melakukan konsolidasi. Seluruh aktivis buruh duduk bersama dan bermusyawarah merumuskan tujuan pembangunan partai buruh secara deliberatif. Hal yang tidak kalah penting dalam agenda membangun partai buruh ini yaitu pentingnya penyelenggaraan pemilu yang tidak mempersulit gerak partai-partai alternatif. Oleh karenanya, segala aturan administratif yang memberatkan dalam regulasi pembentukan partai politik saat ini perlu direvisi untuk meningkatkan kualitas demokratisasi dan demokrasi yang lebih baik di Indonesia.
\end{abstract}

Kata Kunci: Buruh; Partai Buruh; Pemilu. 


\section{Latar Belakang}

Gerakan buruh di Indonesia sebenarnya memiliki kekuatan yang besar. Akan tetapi kekuatan yangbesar tersebutbelum terorganisir menjadi satu kekuatan yang terpadu secara politis, akhirnya gerakan buruh kerap menjadi sub-ordinat bagi kepentingan-kepentingan elite. Gerakan yang bertopang pada basis massa ini terkonversi menjadi ihwal kuantitatif bagi kepentingan elite. Karena tidak bisa dipungkiri lagi, gerakan buruh telah menjadi penyangga bagi partai-partai politik tertentu. Angka yang riil tentang jumlah anggota pada setiap pabrik di pelbagai daerah, misal, menjadi "senjata" yang digunakan partai politik tertentu saat memprotes kebijakan pemerintah yang sedang berkuasa. Catatan ini menjadi refleksi penting bagi gerakan buruh di Indonesia yang besar namun belum mencapai kemandiriannya.

Analisis yang hadir mengapa gerakan buruh belum mencapai kemandirian di antaranya karena cikal bakal gerakan buruh di Indonesia bukan transisi dari masyarakat feodal ke kapitalisme industri seperti di Eropa. Kehidupan masyarakat Indonesia demikian kental dengan budaya primordial, maka halhal terkait etnis, agama, dan kelompok lebih dominan dibanding isu buruh. Dalam hal ini, ada kondisi objektif yang tidak bisa dinafikan, yakni tentang Indonesia sebagai negara kesatuan, yang di dalamnya terdapat beragam agama, suku, etnis dan ras. Keragaman inilah yang menjadikan Indonesia negara pluralis. Namun, seperti dua sisi dalam satu koin, dengan keragaman agama, suku, etnis dan ras, mengkondisikan Indonesia menjadi sangat rentan dengan berbagai konflik karena hadirnya pelbagai kepentingan yang berbeda. Ketika kepentingan yang berbeda dan tidak jarang bersifat konfrontatif itu muncul ke permukaan, maka pada waktu yang bersamaan akan terjadi tarik-menarik kepentingan dan akan memunculkan pelbagai macam konflik kepentingan, yang berimbas pada seluruh elemen masyarakat serta mengganggu situasi Indonesia secara umum. Di sisi lain, pembentukan organisasi-organisasi politik dan sosial baru yang secara terang-terangan mendasarkan diri pada loyalitas etnis dan agama memunculkan kekhawatiran mengenai munculnya kembali perpecahan-perpecahan politis lama, khususnya perpecahan etnis, agama dan ideologi. ${ }^{1}$ Semangat primordialisme bila tanpa dilengkapi rasionalitas yang didasarkan atas pertimbangan demi kepentingan bersama justru bisa berbahaya dan rentan terjebak pada populisme primordial. Dengan kondisi ini, maka tak heran gerakan buruh tidak mampu memiliki suara yang signifikan. Setelah Orde Baru runtuh, menghadapi pemilu 1999 beberapa pemimpin organisasi buruh membangun partai politik. Ada Partai Pekerja Indonesia (PPI), Partai Buruh Nasional (PBN), Partai Solidaritas Pekerja Seluruh Indonesia (PSPSI) dan Partai Solidaritas Pekerja (PSP). Ada juga Partai Rakyat Demokratik (PRD), walaupun tidak menamakan langsung dirinya sebagai partai buruh tetapi sudah lama organisasi ini membangun basis buruh lewat kerja politik underground saat Orde Baru berkuasa. Namun, seperti yang kita tahu, deretan partai yang mendaulat diri sebagai partainya buruh tidak mendapatkan suara signifikan dalam pemilu 1999. Begitu pula pada pemilu 2004 dan 2009, partai politik yang mengatas-namakan buruh pun kembali gagal. Tahun 2014, tanpa partai buruh, suara gerakan buruh malah terpecah. Sedangkan untuk tahun 2019, gerakan buruh malah ada yang terjun dalam populisme kandidat calon presiden tertentu. Dengan kata lain, partaipartai buruh selalu layu sebelum berkembang.

Dalam satu dekade terakhir, jumlah buruh di Indonesia sebenarnya terus meningkat. Data yang dirilis BPS menunjukkan pada

1 Arief Budiman, The 1998 Crisis: Change and Continuity in Indonesia, in Reformasi: Crisis and Change in Indonesia, ed. Arief Budiman, Barbara Hatley, and Damien Kingsbury (Melbourne: Monash Asia Institute, 1998), 87-99. 
tahun 2008 proporsinya 27,5 persen, sedangkan pada tahun 2017 mencapai hampir 40 persen populasi penduduk berusia 15 tahun ke atas. Dari 40 juta lebih pekerja yang bekerja dalam sektor formal, menurut data yang dilansir Kementerian Ketenagakerjaan (2017) mencatat hanya ada sekitar 2,7 juta orang yang terdaftar sebagai anggota serikat pekerja. Terlepas dari tingkat akurasi data tersebut yang masih diperdebatkan, dalam realitas politik Indonesia saat ini, suara buruh selalu dijadikan rebutan partai-partai politik saat pemilu.

Walaupun pengaruhnya cukup besar dalam mempengaruhi gerakan politik buruh, kondisi objektif tentang kelahiran gerakan buruh di Indonesia yang berbeda dengan jejak kelahiran gerakan buruh di negara-negara lahirnya kapitalisme di Eropa, sifatnya tidak determinan. Kemungkinan-kemungkinan intervensi untuk membuka cakrawala lain tentang gerakan buruh dalam pertarungan politik masih terbuka. Kini, wacana buruh masuk dalam pertarungan politik lewat pemilu sudah mulai gencar. Bahkan, tahun 2014 slogan buruh "go politic" sudah ramai dibicarakan dan menjadi materi konsolidasi di dalam internal gerakan buruh. Gerakan buruh melakukan eksperimentasi politik menjadi peserta pemilu sudah dikerjakan dengan konteks yang beragam. Namun karena tidak ada partai buruh yang menjadi payung, maka buruh harus masuk ke partai-partai yang sudah ada.

Secara historis, gerakan buruh di Indonesia, sejak kelahirannya, merupakan gerakan politik. Seperti ditunjukkan oleh Vereenigingvan Spooren en Tramweg Personeel atau Perhimpunan Pekerja Trem dan Kereta Api (VSTP), Perkumpulan Bumiputera Pabean (PBP), Persatuan Pegawai Pegadaian Bumiputera (PPPB), Personeel Fabriek Bond atau Himpunan Pekerja Pabrik (PFB) yang berdiri awal tahun 1900-an, watak politiknya sangat kuat. Konteks sosial kelahiran gerakan lah yang paling menentukan kuatnya watak politik gerakan buruh. ${ }^{2}$ Dalam situasi kontemporer, sebagai gerakan politik, sudah selaiknya buruh memiliki partainya sendiri. Terlebih, permasalahan politik buruh sebenarnya bukan hanya perkara soal ekonomi, yang mana tiap tahun setiap aksi May Day (Hari Buruh Sedunia), seperti menjadi hajatan rutin gerakan buruh yang menuntut perbaikan upah dan kondisi kerja. Tuntutan tersebut tidak salah, namun belum mampu menjawab problem mendasar dari masalah yang dituntut tersebut. Kenaikan upah memiliki imbas yang tidak begitu signifikan selama sistem ekonomi yang menopang kebijakan politik upah murah tidak berubah. Oleh karenanya sebuah partai berbasis politik buruh menjadi penting keberadaannya untuk mengartikulasikan kepentingan-kepentingan buruh dan rakyat yang lebih holistik.

Selama ini, setidaknya pasca reformasi, buruh mengambil positioning dengan membangun akar rumput sebagai preseur group kepada rezim pemerintah yang berkuasa. Namun posisi ini tidak bisa selamanya dilakukan. Gerakan buruh harus berdiri setara dengan aktor-aktor lain sebagai bagian stakeholder dalam pembuatan kebijakan publik. Buruh yang tidak menyadari bahwa kedudukan seimbang dan setara di hadapan para pemilik kapital akan terperangkap sistem dan menjadi sistem produksi. ${ }^{3}$ Untuk membongkar sistem ekonomi yang tidak pro terhadap buruh, maka buruh harus mampu menembus logika normatif good governance yang selalu memenangkan sistem ekonomi pasar. Karena posisi preseur group tidak bisa menjamin suara buruh mampu mendobrak pintu-pintu kebijakan yang sudah dikawal oleh

\footnotetext{
2 Sigit Rochadi, "Dualitas Dalam Gerakan Buruh Di Indonesia," SOSIOHUMANIKA: Jurnal Pendidikan Sains Sosial Dan Kemanusiaan, 9(1) Mei 2016 9, no. 1 (2016): 89-104.

3 A Suwignyo, Buruh Bergerak, Membangun Kesadaran Kelas (Jakarta: Friedrich Ebert Stiftung, 2012).
} 
elite. Bisa jadi, sesekali gerakan buruh berhasil membawa kepentingan buruh, namun dari pembacaan penulis, yang sering terjadi justru adalah kegagalan demi kegagalan yang malah bisa mengakibatkan demoralisasi bagi gerakan buruh.

Sudah saatnya gerakan buruh beranjak kepada tahap penguatan politik, tak lain yaitu terjun langsung ke ranah politik. Ketika beberapa tahun ini gerakan buruh "go politic" dengan cara berpartisipasi menjadi calon legislatif (bahkan calon pemimpin) melalui partai-partai politik sudah mulai berjalan, maka ke depan gerakan buruh harus menunjukan kemandiriannya melalui partai politiknya sendiri: partai buruh.

Akan tetapi cita-cita membangun partai politik oleh buruh akan menjadi tembok yang sulit didobrak bila tidak diiringi oleh penyelenggaraan pemilu yang berintegritas serta memberikan peluang demokrasi yang lebih substantif. Oleh karenanya, dalam hal ini pemerintah dan pihak-pihak yang terkait dalam penyelenggaraan pemilu, perlu mulai memperhatikan suara-suara yang saat ini belum teraktualisasikan dengan baik, khususnya aspirasi gerakan buruh dalam penyelenggaraan pemilu di Indonesia.

Dari kondisi yang dijelaskan di atas, maka artikel ini merupakan ikhtiar untuk melakukan refleksi dan elaborasi dalam mengkaji kemungkinan (gerakan) buruh untuk melangkah pada tahap penguatan politik dengan membangun partai politiknya sendiri dan mengikuti pemilu yang demokratis. Tujuan dari penulisan artikel ini, selain untuk kembali membuka imajinasi tentang partai politik berbasis buruh, juga untuk mengetahui kemungkinan strategi gerakan buruh yang bisa digunakan dalam membangun partai politik. Adapun metode kajian yang digunakan pada kajian ini adalah studi kepustakaan dan fenomenologis, yakni dengan mengamati pada realitas politik kontemporer dan beberapa persitiwa terkait dengan kajian potensi gerakan buruh dalam membangun partai politik.

\section{Sejarah Gerakan Buruh}

Saat masa-masa kolonial, buruh merupakan sebutan bagi kelompok masyarakat di koloni yang termasuk sebagai kaum pekerja, kuli, petani, pegawai pemerintah, buruh kereta api, perkebunan, pertambangan industri, jasa, pelabuhan dan sebagainya. ${ }^{4}$ Namun kini, terma "buruh" dalam kosakata keseharian masyarakat Indonesia memiliki kesan yang kurang baik. Ketika media massa memberitakan aksi May Day menuntut kenaikan upah, cibiran dari kalangan kelas menengah yang sejatinya juga bagian dari 'buruh' sering hadir di media sosial. Kenaikan upah menjadi isu yang melekat dalam setiap aksi mogok kerja dan demonstrasi serikat kerja di Indonesia, khususnya pasca reformasi. Isu ini seolah menjadi isu tunggal yang diperjuangkan. ${ }^{5}$ Padahal, kini gerakan buruh secara bertahap mulai mengartikulasikan tuntutan yang berkelindan dengan isu-isu kemanusian yang lebih luas.

Buruh diasosiasikan sebagai kelompokyang sering membuat macet jalan, buat keributan dan sebagainya. Buruh disebut sebagai pihak yang tidak tahu diri, karena banyak menuntut kenaikan upah yang dinilai akan mengancam masa depan ekonomi (investasi) Indonesia. Padahal, perlu diakui bahwa banyak hasil perjuangan buruh yang diperoleh dan dirasakan langsung sekarang oleh pihak-pihak yang mengaku sebagai karyawan/pegawai (tidak mau disebut sebagai buruh): delapan jam kerja, tunjangan hari raya (THR), jaminan sosial, cuti hamil, dll. Semuanya bisa didapat bukan karena kebaikan korporasi, tapi melalui perjuangan yang berdarah-darah.

4 J Ingleson, "Perkotaan, Masalah Sosial, \& Perburuhan Di Jawa Masa Kolonial," (Jakarta: Komunitas Bambu, 2013).

5 M Zuhdan, "Perjuangan Gerakan Buruh Tidak Sekedar Upah Melacak Perkembangan Isu Gerakan Buruh Di Indonesia Pasca Reformasi," Jurnal Ilmu Sosial Dan Ilmu Politik 17, no. 3 (2014): 272-90. 
Dalam epos kapitalisme, buruh adalah tulang punggung. Tanpa buruh, tidak akan pernah terjadi proses produksi. Dalam pandangan Marxian, ada masyarakat yang memiliki alat produksi dan memiliki kendali atas tenaga kerja, ada sebagian besar masyarakat yang hanya memiliki tenaga kerja saja. Ini lah dua kelas dominan yang saling berkonfrontasi dalam kapitalisme: kelas kapitalis dan kelas proletar. Dua kelas tersebut memiliki kontradiksi dalam kepentingan yang tidak terdamaikan. Para kapitalis hidup melalui nilai lebih yang diambil dari tenaga kerja proletar. Kondisi ini menyebabkan antagonisme kelas yang mendominasi dengan yang didominasi. Antagonisme kelas inilah yang berlangsung sejak lama dalam setiap perubahan sejarah yang terjadi dalam perkembangan masyarakat di dunia. ${ }^{6}$

Segala macam produk yang dikonsumsi oleh manusia tidak datang dengan sendirinya, semua melalui proses sentuhan tangantangan terampil buruh sampai akhirnya produk tersebut hadir untuk siap digunakan/ dikonsumsi. Buruh menjual tenaga kerjanya kepada para pemilik alat-alat produksi (perusahaan, tanah dll). Pada umumnya, perekonomian dikatakan bersifat kapitalistik saat sebagian besar atau sejumlah porsi yang signifikan dari alat-alat produksi yang ada di dalamnya, seperti ladang pertanian, perkebunan, pabrik-pabrik, dan mesinmesin, dimiliki oleh sektor swasta, bukan oleh pemerintah. ${ }^{7}$ Dalam epos kapitalisme, sebagian waktu buruh digunakan untuk menutup biaya hidup sang buruh beserta keluarganya dengan mendapatkan upah. Sementara sebagian waktu lainnya dicurahkan untuk kerja yang menghasilkan nilai lebih bagi

6 Edward Royce, Classical Social Theory and Modern Society Marx, Durkheim, Weber, (London: Rowman \& Littlefield, 2015).

7 William J Baumol, Robert E. Litan, and Carl J. Schramm., Good Capitalism, Bad Capitalism: Kapitalisme Baik, Kapitalisme Buruk, Dan Ekonomi Pertumbuhan Dan Kemakmuran (Jakarta: Gramedia Pustaka Utama, 2010). para pemilik modal karena kerja buruh tidak dibayar. ${ }^{8}$ Namun apa yang didapatkan oleh buruh tidak setimpal dengan kerja keras yang telah dikeluarkan. Para pemilik perusahaan berhasil mencuri "nilai lebih" dari kerja-kerja buruh. Nilai lebih adalah sumber profit dan kemakmuran bagi para pemilik kapital. Buruh ditekan agar tujuan sang pemilik kapital tercapai. Kerja sebagai aktualisasi diri manusia tidak hadir dalam kerja kapitalistik karena eksploitasi sudah tertanam sejak di dalam pabrik.

Kondisi demikian yang membuat para buruh mengorganisir diri dan membangun serikat buruh yang berjuang untuk mendorong peningkatan kesetaraan serta keadilan sosial. Serikat buruh adalah ikhtiar kolektif dalam memperbaiki nasib agar tidak tergilas oleh kekuatan kapital.

Sejarah gerakan buruh (populer) dunia bisa ditelusuri melalui sejarah peringatan May Day (Hari Buruh Sedunia) yang diperingati setiap tanggal 1 Mei. Sejarah singkatnya, pada tahun 1886, para buruh Amerika Serikat melakukan rentetan aksi demonstrasi menuntut penurunan jam kerja dan kenaikan upah yang layak. Saat itu kondisi kapitalisme begitu vulgar, tidak menempatkan manusia sebagaimana layaknya manusia, jam kerja sampai 16 jam per hari dengan kondisi kerja yang buruk. Awal April 1886, ratusan ribu buruh mengorganisir diri dengan bergabung dalam Knight of Labour untuk melawan hegemoni para pemilik kapital (borjuis). Tanggal 1 Mei 1886 demonstrasi semakin menyebar ke pelbagai tempat di Amerika Serikat dengan diikuti sampai 500 ribu buruh.

Para pemilik kapital dan pemerintah tidak tinggal diam, mereka mengeluarkan dana sebesar US\$ 2.000 untuk membeli mesin yang digunakan menghadapi para buruh. Akhirnya demonstrasi pun ricuh. Berselang 2 hari, tanggal 3 Mei 1886, untuk meredam

8 Zuhdan, "Perjuangan Gerakan Buruh Tidak Sekedar Upah Melacak Perkembangan Isu Gerakan Buruh Di Indonesia Pasca Reformasi.” 
aksi buruh, pemerintah menginstruksikan polisi menghentikan demonstrasi di salah satu pabrik McCormick. Tindakan kekerasan dilakukan polisi dengan cara menembaki sejumlah buruh yang sedang mogok kerja. Ada empat buruh yang tewas dalam kejadian tersebut. Hal ini menciptakan kemarahan dari kalangan buruh.

Bundaran Haymarket, Chicago menjadi saksi bisu kembalinya tragedi berdarah. Tanggal 4 Mei 1886, para buruh kembali turun melakukan mogok kerja dengan jumlah massa yang semakin besar sebagai bentuk protes tindakan kekerasan dan brutal dari polisi satu hari sebelumnya. Aksi damai tersebut tersulut menjadi tragedi. Setelah beberapa buruh membubarkan diri karena faktor cuaca yang sedang buruk dan juga atas perintah polisi yang sedang berjaga, tiba-tiba sebuah bom meledak di tengah barisan polisi yang mengakibatkan satu polisi tewas. Kemudian, kejadian tersebut dibalas oleh polisi dengan kembali menembak ke kumpulan buruh secara membabi buta. Diperkirakan terdapat puluhan buruh yang tewas akibat penembakan tersebut.

Tiga tahun setelah kejadian tersebut, Kongres Sosialis Dunia menetapkan setiap tanggal 1 Mei sebagai hari buruh sedunia. Tragedi Haymarket bukan semata soal tuntutan delapan jam kerja sehari yang kini dinikmati oleh para pekerja di seluruh dunia. Lebih dari itu, tragedi Haymarket adalah harapan dan perjuangan untuk kehidupan yang lebih berkeadilan; satu perjuangan yang sampai saat ini belum usai.

Ulasan sejarah singkat di atas merupakan dasar bahwa gerakan buruh merupakan gerakan politik. Di beberapa negara maju, seperti Inggris dan Australia, gerakan buruh sudah mewujud dalam organisasi modern; partai politik. Kekuatan partai buruh memiliki bargaining position yang besar dan mampu menjadi bagian penting dalam proses tata pemerintahan di negara-negara tersebut.
Tantangan ke depan bagi buruh akan semakin meningkat. Di era globalisasi melahirkan ketidakseimbangan kekuatan antara buruh dan pemilik kapital. ${ }^{9}$ Globalisasi menciptakan ragam perubahan tanpa henti yang begitu cepat. Teknologisasi proses produksi merubah corak produksi para buruh. Contoh konkret yang kini dirasakan buruh adalah pasar kerja fleksibel yang menghimpit ruang gerak buruh. Ketika buruh tidak bisa menandingi kecepatan gerak globalisasi, maka buruh akan tersingkirkan untuk memenuhi kepentingan kapital. Kondisi demikian yang mendorong gerakan buruh tetap harus hidup, setia dengan tujuannya: memperjuangkan kehidupan yang adil.

\section{Buruh dalam Eskalasi Politik Pasca Reformasi}

Konteks Indonesia, May Day baru kembali bebas diperingati setelah Orde Baru tumbang. Saat Orde Baru, buruh didepolitisasi sedemikian rupa. Melalui politik eufisme, terma buruh diganti dengan kata karyawan. Penggantian kata ini menciptakan "distingsi" antara sang karyawan dan buruh seperti yang sering terjadi sekarang. Padahal di hadapan kapitalisme, semua sebutan tersebut adalah sama.

Saat zaman awal kemerdekaan (19451965), bahkan saat zaman kolonial, gerakan buruh begitu aktif dalam dinamika politik. Misal saat tahun 1920-an, setelah kegagalan pemberontakan Partai Komunis Indonesia (PKI) terhadap pemerintah kolonial, Partai Sarekat Islam (PSI) dan Partai Nasional Indonesia (PNI) menjadi partai yang aktif membangun serikat buruh untuk membangun basis keanggotaan mereka. ${ }^{10}$ Namun setelah Orde Baru berkuasa, rezim berhasil melakukan 9 J. E Stiglitz, Frontiers of Development Economics: The Future in Perspective (World Bank and Oxford University Press, 2001).

10 Moh Didit Saleh, "Belajar Pada Gerakan Buruh 'Go Politic” (Dipresentasikan dalam diskusi publik yang diselenggarakan Koperasi Riset Purusha dengan tajuk "Buruh Go Politic" di Owl House Coffe, Jakarta pada 19 Desember 2015). 
kooptasi aspirasi politik dengan melakukan restrukturisasi yang membatasi buruh hanya boleh bersuara pada fungsi sosio-ekonomis dalam pemenuhan kesejahteraan buruh. ${ }^{11}$ Gerakan buruh saat Orde Baru dikontrol dengan kebijakan "single union", gerakan buruh disatukan dalam satu konfederasi di bawah payung Serikat Pekerja Seluruh Indonesia (SPSI) yang membuat para buruh tidak memiliki akses untuk menyampaikan gagasan politiknya. Rezim Orde Baru berhasil membangun pemahaman bahwa partisipasi buruh dalam politik adalah hal yang buruk yang menjadi penghambat bagi tujuan pemenuhan kesejahteraan buruh. ${ }^{12}$

Setelah reformasi, pintu kebebasan bagi buruh untuk melakukan kerja politik kembali terbuka. Tercipta sebuah political opportunity structure. Pemeritah berhasil meratifikasi Konvesi International Labour Organization (ILO) No. 101 tentang kebebasan buruh untuk berserikat yang membuka peluang bagi buruh relatif bebas untuk berorganisasi (berserikat). Pada tahun 1999, terdaftar 68 serikat buruh tingkat nasional di Kementerian Tenaga Kerja Republik Indonesia. Angka itu melonjak tajam menjadi 115 serikat buruh pada tahun 2002. Menyadari pentingnya gerakan yang kuat, beberapa serikat buruh bergabung dalam konfederasi. Hingga akhir tahun 2014, terdapat tiga konfederasi, yakni: Konfederasi Serikat Buruh Sejahtera Indonesia (KSBSI), Konfederasi Serikat Pekerja Seluruh Indonesia (KSPSI), dan Konfederasi Serikat Pekerja Indonesia (KSPI). Di sisi lain, terdapat puluhan serikat buruh, baik gerakan yang murni dilakukan oleh buruh maupun Lembaga Swadaya Masyarakat (LSM) yang bergerak dalam bidang perburuhan. ${ }^{13}$

11 M Ford, Economic Unionsm and Labour's Poor Performance in Indonesia's 1999 and 2004 Elections (Sydney: AIRAANZ, 2005).

12 B.H Juliawan, Menantang Elite: Peluang Partisipasi Buruh Dalam Pemilu Dalam Kebangkitan Gerakan Buruh: Refleksi Era Reformasi (Jakarta: Marjin Kiri, 2014).

13 Rochadi, "Dualitas Dalam Gerakan Buruh Di Indonesia."
Gerakan buruh pasca Soeharto mengalami dinamika dan melahirkan keragaman pandangan para pengamat politik dalam membaca gerakan buruh di Indonesia. Melalui pembacaan kritis yang dilakukan Habibi, ${ }^{14}$ ada beberapa kecenderungan pandangan dalam melihat gejolak gerakan buruh di Indonesia. Pertama, ada sebagian pengamat yang menilai buruh bukanlah kelompok yang solid. Hal ini terjadi karena dampak warisan dari otoritarianisme Soeharto yang menyebabkan buruh terlalu terpecah belah dan tidak bisa mendesakkan kepentingannya sebagai kelompok. ${ }^{15}$ Buruh tidak memiliki rasa kebersamaan sebagai kelompok dan buruh seringkali justru terjebak dalam gaya hidup konsumtif. ${ }^{16}$ Kedua, organisasi buruh dianggap tetap lemah meskipun telah lahir peraturan yang menyediakan payung bagi lahirnya pelbagai serikat buruh. Bukannya membantu lahirnya organisasi buruh yang independen, peraturan yang ada justru dianggap sebagai pemecah belah gerakan buruh. ${ }^{17}$ Kecenderungan ketiga menunjukkan kegagalan gerakan buruh dalam pertarungan pemilu. ${ }^{18}$ Pandangan yang telah dijelaskan menunjukkan tentang kegagalan gerakan buruh dalam memberikan pengaruh politiknya pascareformasi.

Dalam kaitannya dengan pemilu, pasca tumbangnya Soeharto setidaknya ada empat model partisipasi buruh yang dicoba dilakukan. Pertama, membangun partai politik dan ikut bersaing dalam perebutan suara seperti yang

14 Muhtar Habibi, "Gerakan Buruh Pasca Soeharto: Politik Jalanan Di Tengah Himpitan Pasar Kerja Fleksibel," Jurnal Ilmu Sosial Dan Ilmu Politik 16, no. 3 (2013): 200-216.

15 Vedi R Hadiz, "The Indonesian Labour Movement: Resurgent or Constrained?," Southeast Asian Affairs, 2002, 130-142.

16 Nicolaas Warouw, "Pekerja Industri Indonesia, Gerakan Buruh, Dan New Social Movement: Merajut Sebuah Kemungkinan," Jurnal Analisis Sosial 10, no. 2 (2005): 1-18.

17 Teri L Caraway, "Freedom of Association: Battering Ram or Trojan Horse?," Review of International Political Economy 13, no. 2 (2006): 210-32.

18 Ford, Economic Unionsm and Labour's Poor Performance in Indonesia's 1999 and 2004 Elections. 
dilakukan pada pemilu 1999, 2004, dan 2009. Kedua, melalui pencalonan sejumlah aktivis buruh dan elite serikat buruh sebagai calon legislatif melalui kontrak individual dengan partai atau melalui kemitraan organisasional. Namun pembentukan kemitraan dengan organisasional dengan partai tidak bisa menjamin tingginya jumlah suara dari buruh. ${ }^{19}$ Akan tetapi, setidaknya model partisipasi ini terus dicoba oleh beberapa gerakan buruh. Salah satunya di Kabupaten Bekasi yang berhasil memberikan kemenangan kecil dengan mengantarkan dua calon legislatif dari Federasi Serikat Pekerja Metal Indonesia (FSPMI) sebagai anggota Dewan Perwakilan Rakyat Daerah (DPRD) pada pemilu legislatif tahun 2014. ${ }^{20}$

Ketiga, partisipasi politik kelompok buruh dengan kontrak politik dengan partai. Model partisipasi ini menemui momentumnya saat pemilu langsung kepala daerah mulai diimplementasikan tahun 2005. Bila ada caloncalon yang ingin mendapatkan dukungan suara dari buruh harus menandatangani kontrak politik dengan serikat buruh. Model keempat adalah yaitu banyak aktivis buruh dan pengurus serikat yang berperan sebagai makelar dan perantara dalam pemilu. Melalui kapasitas personal dan kemampuannya dalam menjaring massa, para aktivis buruh tersebut menjadi "tim sukses" bagi calon-calon yang mengikuti pemilukada. ${ }^{21}$

Empat model di atas adalah strategi yang paling memungkinkan yang bisa dikerjakan oleh buruh di tengah realitas politik saat ini. Kondisi politik Indonesia saat ini mengalami defisit demokrasi karena demokratisasi justru dikuasai dan dikendalikan oleh kelompok oligarki yang memiliki kepentingan

19 Juliawan, Menantang Elite: Peluang Partisipasi Buruh Dalam Pemilu Dalam Kebangkitan Gerakan Buruh: Refleksi Era Reformasi.

20 Saleh, "Belajar Pada Gerakan Buruh 'Go Politic.”'

21 Juliawan, Menantang Elite: Peluang Partisipasi Buruh Dalam Pemilu Dalam Kebangkitan Gerakan Buruh: Refleksi Era Reformasi. predatory. ${ }^{22}$ Persoalan defisit demokrasi bukan karena tidak adanya kebebasan politik tetapi tidak berfungsinya kontrol publik dalam pengendalian kekuasaan. Hal inilah yang dialami oleh buruh, mereka tidak bisa melakukan kontrol publik, tidak ada representasi politik yang mumpuni dan mampu mengawal kepentingan-kepentingan buruh dalam penentuan kebijakan. Dari keempat model yang telah dijelaskan, harus diakui, belum berhasil mewujudkan gerakan kemandirian politik bagi buruh. Memang, selama periode awal demokratisasi di Indonesia kelompok buruh tidak mampu menunjukan pengaruh dan kekuatan. ${ }^{23}$ Walaupun ruang untuk memperjuangkan kepentingan buruh tersedia, namun ternyata belum bisa menjamin peran aktif buruh dalam keberlanjutan tahap demokratisasi.

\section{Membangun Kembali Partai Politik Buruh}

Semangat reformasi setelah runtuhnya Orde Baru sempat membangkitkan dan mendorong gerakan buruh untuk turut serta dalam proses demokratisasi melalui pemilu. Tahun 1999 hadir Partai Pekerja Indonesia (PPI), Partai Buruh Nasional (PBN), Partai Solidaritas Pekerja Seluruh Indonesia (PSPSI), Partai Solidaritas Pekerja (PSP) dan Partai Rakyat Demokratik (PRD). Namun dari lima partai tersebut tidak ada satu pun partai yang memperoleh satu kursi di parlemen.

Pemilu tahun 2004 hanya menyisakan satu partai buruh yang berhasil lolos verifikasi Komisi Pemilihan Umum (KPU) dan menjadi kontestan, yaitu partai Buruh Sosial Demokrat (PBSD). Partai ini merupakan perubahan nama dari PBN yang sebelumnya ikut pada pemilu 1999. Namun partai ini kembali gagal memperoleh kursi dalam pemilu nasional, yang hanya mendapatkan 636.397 suara $(0,56 \%)$.

22 R Robison and V Hadiz, Reorganizing Power In Indonesia: The Politics of Oligarchy in an Age of Markets (London: Routledge, 2004).

23 O Tornquist, "Labour and Democracy? Reflections on The Indonesian Impasse," Journal of Contemporary Asia 43, no. 3 (2004): 377-99. 
Tabel 1. Suara Partai yang Memiliki Basis Buruh dalam Pemilu 1999, 2004, dan 2009

\begin{tabular}{cccccc}
\hline \multicolumn{2}{c}{ Pemilu 1999} & \multicolumn{2}{c}{ Pemilu 2004 } & \multicolumn{2}{c}{ Pemilu 2009 } \\
\hline Partai & Suara & Partai & Suara & Partai & Suara \\
\hline PBN & 111.629 & PBSD & 636.397 & PB & 265.203 \\
PPI & 63.934 & & & PPPI & 745.625 \\
PSPI & 61.105 & & & & \\
PSP & 61.105 & & & & \\
PRD & 78.730 & & & & 1.010 .828 \\
Jumlah & 365.205 & & 636.397 & $0,97 \%$ \\
Persentase & $0,35 \%$ & & $0,56 \%$ & & \\
\hline
\end{tabular}

Sumber: Komisi Pemilihan Umum, 2019.

Tahun 2009, partai yang memiliki kaitan dengan buruh yang mengikuti pemilu adalah Partai Buruh (PB) yang tak lain merupakan nama baru dari PBSD. Selain PB ada Partai Pengusaha dan Pekerja Indonesia (PPPI) yang sebenarnya cukup kontradiktif karena partai ini justru dipimpin oleh seorang pengusaha, Daniel Hutapea. PB mendapatkan 265.203 suara (0,25\%) dan PPPI memperoleh 745.625 suara $(0,72 \%)$. Berarti dua partai ini kembali gagal mewujudkan cita-cita menempatkan perwakilan buruh dalam parlemen.

Pengalaman buruh dalam membangun partai dan mengikuti pemilu adalah pelajaran berharga. Kegagalan yang pernah terjadi perlu dievaluasi bagi gerakan buruh untuk mempersiapkan gerakan yang lebih matang. Alih-alih membunuh semangat kolektif gerakan buruh dalam berpolitik, justru kondisi tersebut perlu untuk mendorong dalam menghidupkan kembali imajinasi kekuatan buruh. Berarti, setelah vakum pada pemilu 2014 lalu, wacana menjalankan model partisipasi buruh dengan membangun partai alternatif perlu digalakkan kembali.

Problem mendasar mengapa gerakan buruh kerap mengalami kegagalan adalah fragmentasi dan konflik internal dalam gerakan buruh itu sendiri. Fragmentasi gerakan buruh merupakan konsekuensi masyarakat pascaotoriter. Pergeseran dan penyusunan kembali kelompok-kelompok politik akan diikuti oleh fragmentasi kelompok, termasuk serikat buruh. ${ }^{24}$ Pada awal-awal masa reformasi (demokratisasi), selama lima tahun pertama lahir 80 federasi serikat buruh. Ketidakmampuan membentuk gerakan barisan yang mumpuni membuat gerakan buruh selalu gagal memanfaatkan ruang politik yang disediakan oleh demokratisasi. ${ }^{25}$ Problem fragmentasi ini pun terbawa sampai saat ini. Alih-alih hadir partai buruh, pemilu tahun 2014 justru semakin mengkotak-kotakan suara buruh. Polarisasi ini terlihat ketika ada Konfederasi Serikat Pekerja Seluruh Indonesia (KSPI) yang mendukung Prabowo, Konfederasi Serikat Buruh Seluruh Indonesia (KSBI) mendukung Jokowi, dan Konfederasi kongres Aliansi Serikat Buruh Indonesia (KASBI) yang tetap memilih independen. ${ }^{26}$ Begitu pula yang terjadi pada pemilu 2019, serikat pekerja kembali terbelah, ada yang menjadi pendukung dua kandidat

24 John Thirkell, Richard Scase, and Sarah Vickerstaff, Labour Relation and Political Change in Eastern Europe (London: Taylor and Francis, 2005).

25 J Suryomenggolo, Kebangkitan Gerakan Buruh (Pengantar) Dalam Kebangkitan Gerakan Buruh: Refleksi Era Reformasi (Jakarta: Marjin Kiri, 2014).

26 Triyono, "Buruh Dalam Pusaran Politik 2014," LIPI, 2014, http://kependudukan.lipi.go.id/en/populationstudy/employment/152-buruh-dalam-pusaranpolitik-2014. 
calon presiden, ada juga yang tetap berdiri secara independen.

Fragmentasi dalam tubuh gerakan buruh mengakibatkan kooptasi oleh partai-partai politik besar. Kooptasi ini bisa kembali menciptakan kondisi politik "penitipan aspirasi" buruh kepada partai-partai yang ada, yang selama ini jelas tidak pernah efektif. Karena elite politik oligarki tidak pernah peduli dengan persoalan buruh, bahkan para elite justru malah merampas dan menunggangi gerakan buruh untuk kepentingan jangka pendek mereka. ${ }^{27}$

Untuk memperjuangkan kepentingan buruh, tidak semata melakukan mobilisasi anggota, namun juga membangun kesadaran politis dan menghimpun kekuatan kolektif yang mumpuni. Kekuatan kolektif buruh merupakan faktor penting dalam menjalin kemitraan strategis dengan elite politik untuk dapat mendikte hasil dan rumusan kebijakan publik. ${ }^{28}$ Dengan kekuatan kolektif buruh pula, partai politik yang mandiri bisa terbangun. Maka, hal yang terus dilakukan oleh gerakan buruh untuk membangun partai yaitu dengan melakukan pendidikan politik kepada seluruh buruh.

Pendidikan politik bukanlah pekerjaan yang mudah. Apalagi di tengah kondisi apatisme warga (dan juga buruh) yang masih besar. Karena politik yang hendak dibangun bukan soal perkara partisipasi pencoblosan saat pemilu, melainkan lebih dari itu, bagaimana buruh bisa merebut dan mempertahankan segala sumber daya yang saat ini kerap dirampas oleh kepentingan segelintir pihak pemerintah dan kapital. Hak-hak normatif buruh saat ini masih sering dinegasikan harus direbut.

Gerakan buruh perlu membangun konstituen yang kuat untuk mendukung kerja politik. Maka, salah satu hal konkret yang

27 Suryomenggolo, Kebangkitan Gerakan Buruh (Pengantar) Dalam Kebangkitan Gerakan Buruh: Refleksi Era Reformasi.

28 M. V Murillo, Labour Unions, Partisan Coalitions, and Market Reforms in Latin America (Cambridge: Cambridge University Press, 2001). bisa dilakukan oleh gerakan buruh adalah melaksanakan penyerapan aspirasi dari bawah. Tidak hanya suara buruh, namun suara rakyat pada umumnya. Penyerapan aspirasi ini adalah bentuk partisipasi langsung dari rakyat (tentunya buruh) untuk mengidentifikasi kebutuhan riil mereka beserta solusi yang bisa ditawarkan langsung dari aspirasi rakyat. Pendekatan bottom up ini penting menjadi antitesa dari kerja-kerja partai politik yang elitis dan kerap tidak mampu mengakomodasi suara-suara rakyat kecil.

Membangun partisipasi melalui penyerapan aspirasi ini sejalan dengan paradigma New Public Service (NPS) yang dalam satu dekade berkembang di beberapa negara. Paradigma NPS memandang rakyat perlu terlibat aktif dalam tata kelola pemerintahan termasuk urusan aktivitas sosial-ekonominya dan penentuan kebijakan. Dengan kata lain, partisipasi rakyat adalah kunci penting. ${ }^{29}$ Nilai-nilai yang diadaptasi dalam paradigma NPS merupakan hasil dialog. Salah satu akar NPS yakni teori warga negara demokratis (democratic citizenship). Dalam teori warga negara demokratis, harus ada jaminan hakhak individu warga melalui berbagai prosedur yang ada dalam menyampaikan gagasan-gagasan dan aspirasi dalam pemenuhan kebutuhan publik. Dalam hal ini, warga negara, termasuk buruh, kemudian perlu melibatkan diri dalam penentuan-penentuan kebijakan dan tata kelola pemerintahan. Semangat itu, meminjam istilah Mansbridge disebut sebagai "public spirit". 30 Semangat publik dimanifestasikan dalam format altruisme warga negara untuk melibatkan diri dalam aktivitas kepemerintahan. Sikap demikian melampaui semata dorongan kepentingan pribadi, melainkan kepentingan publik dan jangka panjang. Semangat publik

29 Janet V Denhardt and Robert B. Denhardt, The New Public Service: Service Not Steering, 4th edition (England: Routledge, 2015).

30 Dodi Faedlulloh, "Local Public Sphere for Discursive Public Service in Indonesia: Habermas Perspective," European Journal of Social Sciences Education and Research 5, no. 1 (2015): 427-32. 
memperhatikan prinsip seperti keadilan, partisipasi publik, dan deliberasi. Keadilan merupakan prinsip yang begitu kuat hingga seseorang dapat merasakan sedang teraniaya atau tereksploitasi yang membuatnya bertahan. Sedangkan partisipasi publik merupakan proses pelibatan warga negara dalam proses penyerapan aspirasi, perencanaan sampai aksi. Kemudian melalui deliberasi, warga negara memperoleh pijakan umum bagi terbangunnya solidaritas dan komitmen bersama.

Hasil identifikasi dari penyerapan aspirasi ini bisa menjadi bukti yang representatif dalam perumusan kebijakan. Secara perlahan, kerjakerja penyerapan aspirasi ini bisa membangun kesadaran politis rakyat. Bila aspirasi tidak diakomodasi, maka rakyat yang sadar dapat memahami peran pemerintah dan partai politik yang "sebenarnya". Hal yang paling sulit dalam tahap pendidikan politik seperti ini adalah konsistensi merawatnya, maka diperlukan kesabaran ekstra dari elemen gerakan buruh untuk secara terus menerus dan konsisten mengawal aspirasi dari bawah untuk mendapatkan kepercayaan langsung dari rakyat dan kalangan buruh sendiri.

Selanjutnya, strategi yang perlu dilakukan untuk menyatukan suara buruh, maka buruh harus segera melakukan konsolidasi (nasional) untuk bersatu membangun kembali partai buruh. Seluruh aktivis buruh yang tersebar di pelbagai serikat di setiap kota harus duduk bersama merumuskan tujuan untuk mengawali langkah tahap pembangunan partai buruh. Konsolidasi ini penting untuk mengikis fragmentasi antar lintas organisasi buruh. Alihalih berpecah karena faktor egoisme elite buruh, harusnya gerakan buruh melakukan kerjasama secara politis. Dalam konteks ini, upaya merefleksikan ulang pemikiran Habermas tentang demokrasi deliberatif menjadi relevan. Demokrasi deliberatif melandasi proses komunikasi yang setara dan terbebas dari dominasi serta kooptasi pihak tertentu, terlebih elite. Relasi yang dibangun bukan hubungan tuan-budak melainkan warga negara. Habermas merealisasikan komunikasi kemanusian itu dalam konsep public sphere (ruang publik). ${ }^{31}$ Demokrasi deliberatif merupakan derivasi ruang publik dalam konteks teori politik.

Bagi gerakan buruh yang terbiasa menggunakan analisis basis kelas, peran ruang publik bisa dinilai kurang efektif karena kemungkinannya memberikan ruang berkolaborasi dengan kelas borjuis. Namun, dalam konteks sesama buruh (sebagai suatu kelas), kehadiran ruang publik menjadi perlu adanya sebagai manifestasi dari etos egaliter dalam berkomunikasi dan membangun opini publik sesama kelas buruh. Melalui kesalingpahaman sebagai subjek komunikasi, sebuah tindakan komunikatif akan mampu berjalan. Akan tetapi bila terjadi pemaksaan kehendak atau bahkan terjadinya disinformasi serta penyampaian kebohongan, maka tindakan komunikasi tersebut berubah menjadi tindakan strategis dan instrumental yang tidak akan berujung pada pencapaian konsensus, melainkan penguasaan dan pemenuhan ambisi tujuan-tujuan pribadi. Hal inilah yang perlu dihindari dalam proses perjuangan membangun sebuah partai buruh. Opini yang hadir kelak akan berperan untuk mempengaruhi segala yang ada dalam ruang publik, baik secara formal maupun informal, untuk melakukan produksi dan sirkulasi diskursus yang secara prinsip merupakan hal yang sangat penting bagi proses demokrasi. ${ }^{32}$

Partisipasi memerlukan suatu dialog terbuka dan keterlibatan pelbagai elemen gerakan buruh secara aktif, serta membutuhkan hak suara dari para partisipan dalam pengambilan keputusan yang dapat mempengaruhi suatu forum. Dalam menyelami proses komunikasi dalam ruang publik, para buruh harus melatih diri untuk menciptakan rasa saling percaya sesama gerakan

31 Jurgen Habermas, The Theory of Communicative Action: Reason and The Rationalization Of Society. Volume I (Boston: Beacon Press, 1984).

32 Faedlulloh, "Local Public Sphere for Discursive Public Service in Indonesia: Habermas Perspective." 
buruh. Melakukan pendewasaan bersamasama dengan saling menutupi perbedaan (yang kadang) tidak substansial. Dengan demikian, harapan membangun lagi partai buruh menjadi mungkin. Secara dialektis, kuantitas-kuantitas rembug bersama yang diselenggarakan dengan konsisten akan menuju kualitas. Bila situasi dan kondisi telah matang, maka partai buruh mampu berdiri.

\section{Hambatan Eksistensi Partai Buruh}

Agenda membangun partai akan tergantung pada seberapa kuat kebutuhan buruh terhadap lembaga kepentingan modern tersebut. ${ }^{33}$ Dalam menghadapi permasalahan perburuhan, gerakan buruh sering melakukan aksi jalanan seperti demonstrasi dan mogok kerja yang begitu disiplin dan militan, di antaranya telah memberikan hasil dalam pemenuhan hak-hak normatif. Namun dalam kondisi terbaru, seperti kontroversi revisi Undang-Undang Ketenagakerjaan, menunjukkan bahwa aksi di jalanan tetap memiliki keterbatasan. Dengan kata lain, gerakan buruh perlu memiliki kekuasaan formal dalam politik Indonesia.

Gerakan buruh yang masih begitu tertatihtatih di Indonesia harus mengorganisir dirinya sendiri sebagai sebuah kekuatan yang koheren. Tidak ada lagi pusat nasional yang mampu berunding atas nama buruh; tidak ada partai politik besar yang mempunyai hubungan organis dengan gerakan buruh..$^{34}$ Oleh karena itu perlu melahirkan kembali kebutuhan akan persatuan buruh dalam skala lebih besar. Agar hubungan organis tersebut terjalin, jalan keluar yang paling mungkin yakni gerakan buruh membangun partai buruhnya sendiri. Namun sayangnya, selalu tercipta situasi 33 Habibi, "Gerakan Buruh Pasca Soeharto: Politik Jalanan Di Tengah Himpitan Pasar Kerja Fleksibel."

34 Vedi R Hadiz, "Mencerminkan Masa Lalu Atau Membayangkan Masa Depan?Kelas Dan Pluralisme Religius Dalam Tenaga Kerja Indonesia," in Politik Multikulturalisme Menggugat Realitas Kebangsaan, ed. Robert W Hefner (Yogyakarta: Impulse dan Penerbit Kanisius, 2007), 435-65. yang menghambat gerakan buruh. Serangan tersebut dalam bentuk instrumen otoritas formal negara. Di luar kepemiluan, gerakan buruh sempat terancam eksistensinya karena hadirnya Rancangan Undang-Undang (RUU) Keamanan Nasional dan UU Organisasi Kemasyarakat Nomor 17 tahun 2013 (yang kini telah diganti dengan hadirnya Peraturan Pemerintah Pengganti Undang-Undang [Perppu] Nomor 2 Tahun 2017). ${ }^{35}$ Terbaru, kontroversi revisi UU Ketenagakerjaan, yang kehadirannya mau tidak mau harus dihadapi oleh gerakan buruh di Indonesia. Selalu ada fokus dan locus perjuangan gerakan buruh yang tidak pernah selesai, satu permasalahan belum tuntas, lahir permasalahan baru bagi gerakan buruh. Di luar arena politik formal seperti pemilu, gerakan buruh diserang oleh pelbagai regulasi yang belum pro terhadap buruh, begitupula dalam konteks kepemiluan. Salah satunya yakni berkenaan dengan aturan main dalam pemilu dan pembentukan partai politik saat ini yang menjadi hambatan terbesar bagi gerakan buruh. Regulasi yang ada saat ini menyulitkan bagi gerakan buruh membangun partai. Ikhtiar membangun partai alternatif terbentur oleh aturan legal-formal yang diformulasikan secara elitis.

Regulasi yang mengatur pembentukan partai politik saat ini, UU No. 2 Tahun 2011 memberikan syarat pendaftaran yang sangat berat. Untuk menjadi peserta pemilu, partai politik harus berbadan hukum. Dalam Pasal 3 (2) mengsyaratkan partai yang dibentuk harus mempunyai kepengurusan minimal 1) $100 \%$ dari jumlah provinsi, 2) $75 \%$ dari jumlah kabupaten/kota di setiap provinsi yang bersangkutan, dan 3) 50\% dari jumlah kecamatan di setiap kabupaten/kota yang bersangkutan. Dalam sejarah regulasi yang mengatur syarat pendirian dan pembentukan partai politik, UU No. 2 Tahun 2011 semakin memberatkan.

35 Habibi, "Gerakan Buruh Pasca Soeharto: Politik Jalanan Di Tengah Himpitan Pasar Kerja Fleksibel.” 
Tabel 2. Syarat Pembentukan Partai Politik Menurut Undang Undang Parpol

Tahun 1999, 2002, 2008 dan 2011

\begin{tabular}{|c|c|c|}
\hline Regulasi & Pembentukan & Kepengurusan \\
\hline \multicolumn{3}{|c|}{ Pasal 2 (1) } \\
\hline UU No. 2 Tahun 1999 & $\begin{array}{l}\text { Paling sedikit } 50 \text { orang WNI } \\
\text { yang telah berusia } 21 \text { tahun }\end{array}$ & Tidak ada \\
\hline \multirow[b]{2}{*}{ UU No. 31 Tahun 2002} & & Pasal 2 (3) \\
\hline & $\begin{array}{l}\text { Pasal } 2(1) \\
\text { Paling sedikit } 50 \text { orang WNI } \\
\text { yang telah berusia } 21 \text { tahun } \\
\text { dengan akta notaris. }\end{array}$ & $\begin{array}{l}\text { mempunyai kepengurusan } \\
\text { minimal 1) 50\% dari } \\
\text { jumlah provinsi, 2) } 50 \% \\
\text { dari jumlah kabupaten/ } \\
\text { kota di setiap provinsi yang } \\
\text { bersangkutan, dan 5) } 25 \% \\
\text { dari jumlah kecamatan di } \\
\text { setiap kabupaten/kota yang } \\
\text { bersangkutan }\end{array}$ \\
\hline \multirow[b]{2}{*}{ UU No. 2 Tahun 2008} & \multirow[b]{2}{*}{$\begin{array}{l}\text { Pasal } 2 \text { (1) } \\
\text { Paling sedikit } 50 \text { WNI yang } \\
\text { telah berusia } 21 \text { tahun dengan } \\
\text { akta notaris. }\end{array}$} & Pasal $3(2)$ \\
\hline & & $\begin{array}{l}\text { mempunyai kepengurusan } \\
\text { minimal 1) 60\% dari } \\
\text { jumlah provinsi, 2) } 50 \% \\
\text { dari jumlah kabupaten/ } \\
\text { kota di setiap provinsi yang } \\
\text { bersangkutan, dan 3) } 25 \% \\
\text { dari jumlah kecamatan di } \\
\text { setiap kabupaten/kota yang } \\
\text { bersangkutan }\end{array}$ \\
\hline \multirow[b]{2}{*}{ UU No. 2 Tahun 2011} & & $\begin{array}{l}\text { Pasal } 3(2) \\
\text { mempunyai } \\
\text { minimal }\end{array}$ \\
\hline & $\begin{array}{l}\text { Pasal } 2(1) \\
\text { Paling sedikit } 30 \text { WNI yang } \\
\text { telah berusia } 21 \text { tahun di } \\
\text { setiap provinsi }\end{array}$ & $\begin{array}{l}\text { 1) } 100 \% \text { dari jumlah } \\
\text { provinsi, 2) } 75 \% \text { dari } \\
\text { jumlah } \\
\text { di sabupaten/kota } \\
\text { di provinsi yang } \\
\text { bersangkutan, dan 3) } 50 \% \\
\text { dari jumlah kecamatan di } \\
\text { setiap kabupaten/kota yang } \\
\text { bersangkutan }\end{array}$ \\
\hline
\end{tabular}

Sumber: Data Diolah Penulis.

Jelas, aturan ini membuat demokrasi jadi semakin mahal. Regulasi ini tentu hanya berlaku bagi partai-partai yang memiliki dana besar dan bagi gerakan buruh hal ini sangat menyulitkan. Alasan umum yang sering digunakan dalam penambahan syarat administratif pendirian partai politik adalah untuk meningkatkan kualitas. Namun alasan tersebut tidaklah sesuai dengan realitas, justru partai-partai yang ada saat ini begitu korup. Setidaknya sepanjang tahun 2014-2019, data yang dilansir Indonesia Corruption Watch (ICW) mencatat ada 254 politisi yang menjadi tersangka korupsi. Bahkan, politik yang berbiaya tinggi ini justru menjadi faktor pendorong terjadinya korupsi massal di parlemen. 
Dengan kondisi demikian, maka kita laik kritis, aturan main dalam pendirian partai merupakan upaya sistematis dalam kembali mengkerangkeng kebebasan berorganisasi dalam hal mendirikan partai politik. Ketika demokrasi dipersempit oleh aturan legalformal, maka kelompok oligarki bisa merayakan konsolidasi dalam arena politik. Dari perspektif demokrasi dan hak asasi manusia (HAM), syarat yang memberatkan pembentukan partai sangat bertentangan dengan hak masyarakat untuk berkumpul dan berorganisasi secara politik. Hal ini mengkondisikan suara elite menjadi satusatunya sumber suara yang memonopoli proses politik di Indonesia. Oleh karena itu, agenda revisi undang-undang tentang partai politik menjadi salah satu hal yang perlu diperjuangkan bagi gerakan buruh dan pihakpihak yang pro demokrasi di Indonesia. Hal ini memang bukanlah pekerjaan yang mudah di tengah situasi masih minimnya agenda perjuangan elektoral dalam gerakan buruh itu sendiri, sehingga respon terhadap regulasi partai politik ini tidak sekuat dan semendesak isu lainnya. Jadi, selain berjuang dalam pemenuhan hak-hak normatif, gerakan buruh dan gerakan masyarakat yang pro demokrasi perlu mengeluarkan energi ekstra agar aturan pendirian partai politik tidak lagi mempersulit atas lahirnya partai-partai alternatif. Pada dasarnya, pemilu merupakan pestanya rakyat, bukan pesta elit oligarki. Oleh karena itu, untuk membangun demokrasi yang lebih berkualitas, pintu berdemokrasi harus dibuka lebar.

\section{Penutup}

Politik alternatif sekarang menjadi sarana yang penting bagi gerakan buruh di Indonesia untuk bisa bersuara. Oleh karenanya, membangun partai buruh merupakan agenda yang penting dalam proses demokratisasi di Indonesia. Sudah saatnya buruh harus terjun menjadi penyeimbang sebagai bagian dari stakeholder dalam mengelola tata pemerintahan Indonesia. Karena kelahiran partai buruh akan menjadi alternatif dari partai-partai hari ini yang bercorak elitis. Peluang tersebut harus diciptakan oleh buruh dengan menciptakan momentum yang tepat.

Untuk membangun konstituen yang kuat dalam mendukung kerja politik buruh, salah satu hal konkret yang bisa dilakukan oleh gerakan buruh adalah melaksanakan penyerapan aspirasi dari bawah sebagai bentuk dari pendidikan politik. Penyerapan aspirasi dengan turun ke basis, mengidentifikasi permasalahan-permasalahan rakyat dan merumuskan bersama tawaran alternatif solusi yang bisa dilakukan, merupakan antitesa kerja partai politik yang ada saat ini. Harapannya mampu membangun kepercayaan dari rakyat dan khususnya dari kalangan buruh sendiri. Selain itu, buruh juga harus segera melakukan konsolidasi nasional. Seluruh aktivis gerakan buruh yang tersebar di pelbagai serikat di Indonesia duduk bersama dan bermusyawarah dalam merumuskan tujuan untuk mengawali langkah pembangunan partai buruh. Namun tujuan membangun partai buruh akan menjadi kerja yang sulit bila persyaratan menjadi peserta pemilu semakin berat dan tidak berintegritas. Oleh karenanya, segala aturan administratif yang memberatkan dalam pembentukan partai politik saat ini (yang berimplikasi pada biaya yang mahal) perlu direvisi untuk kualitas demokratisasi dan demokrasi yang lebih baik di Indonesia. 


\section{DAFTAR PUSTAKA}

Baumol, William J, Robert E. Litan, and Carl J. Schramm. Good Capitalism, Bad Capitalism: Kapitalisme Baik, Kapitalisme Buruk, Dan Ekonomi Pertumbuhan Dan Kemakmuran. Jakarta: Gramedia Pustaka Utama, 2010.

Budiman, Arief. "The 1998 Crisis: Change and Continuity in Indonesia." In Reformasi: Crisis and Change in Indonesia, edited by Arief Budiman, Barbara Hatley, and Damien Kingsbury, 87-99. Melbourne: MOnash Asia Institute, 1998.

Caraway, Teri L. "Freedom of Association: Battering Ram or Trojan Horse?" Review of International Political Economy 13, no. 2 (2006).

Denhardt, Janet V, and Robert B. Denhardt. The New Public Service: Service Not Steering. 4th edition. England: Routledge, 2015.

Faedlulloh, Dodi. "Local Public Sphere for Discursive Public Service in Indonesia: Habermas Perspective." European Journal of Social Sciences Education and Research 5, no. 1 (2015): 427-32.

Ford, M. Economic Unionsm and Labour's Poor Performance in Indonesia's 1999 and 2004 Elections. Sydney: AIRAANZ, 2005.

Habermas, Jurgen. The Theory of Communicative Action: Reason and The Rationalization Of Society. Volume I. Boston: Beacon Press, 1984.

Habibi, Muhtar. "Gerakan Buruh Pasca Soeharto: Politik Jalanan Di Tengah Himpitan Pasar Kerja Fleksibel.” Jurnal Ilmu Sosial Dan Ilmu Politik 16, no. 3 (2013).

Hadiz, Vedi R. "Mencerminkan Masa LaluAtau Membayangkan Masa Depan?Kelas Dan Pluralisme Religius Dalam Tenaga Kerja Indonesia." In Politik Multikulturalisme Menggugat Realitas Kebangsaan, edited by Robert W Hefner, 435-65. Yogyakarta: Impulse dan Penerbit Kanisius, 2007.
-. "The Indonesian Labour Movement: Resurgent or Constrained?" Southeast Asian Affairs, 2002.

Ingleson, J. Perkotaan, Masalah Sosial, Eु Perburuhan Di Jawa Masa Kolonial. Jakarta: Komunitas Bambu, 2013.

Juliawan, B.H. Menantang Elite: Peluang Partisipasi Buruh Dalam Pemilu Dalam Kebangkitan Gerakan Buruh: Refleksi Era Reformasi. Jakarta: Marjin Kiri, 2014.

Murillo, M. V. Labour Unions, Partisan Coalitions, and Market Reforms in Latin America. Cambrdige: Cambridge University Press, 2001.

Robison, R, and V Hadiz. Reorganizing Power In Indonesia: The Politics of Oligarchy in an Age of Markets. London: Routledge, 2004.

Rochadi, Sigit. "Dualitas Dalam Gerakan Buruh Di Indonesia." SOSIOHUMANIKA: Jurnal Pendidikan Sains Sosial Dan Kemanusiaan, 9(1) Mei 2016 9, no. 1 (2016).

Royce, Edward. Classical Social Theory and Modern Society Marx, Durkheim, Weber. London: Rowman \& Littlefield, 2015.

Saleh, Moh Didit. "Belajar Pada Gerakan Buruh 'Go Politic."' Dipresentasikan dalam diskusi publik yang diselenggarakan Koperasi Riset Purusha dengan tajuk "Buruh Go Politic" di Owl House Coffe, Jakarta pada 19 Desember 2015, 2015.

Stiglitz, J. E. Frontiers of Development Economics: The Future in Perspective. World Bank and Oxford University Press, 2001.

Suryomenggolo, J. Kebangkitan Gerakan Buruh (Pengantar) Dalam Kebangkitan Gerakan Buruh: Refleksi Era Reformasi. Jakarta: Marjin Kiri, 2014.

Suwignyo, A. Buruh Bergerak, Membangun Kesadaran Kelas. Jakarta: Friedrich Ebert Stiftung, 2012. 
Thirkell, John, Richard Scase, and Sarah Vickerstaff. Labour Relation and Political Change in Eastern Europe. London: Taylor and Francis, 2005.

Tornquist, O. "Labour and Democracy? Reflections on The Indonesian Impasse." Journal of Contemporary Asia 43, no. 3 (2004).

Triyono. "Buruh Dalam Pusaran Politik 2014.” LIPI, 2014. http://kependudukan. lipi.go.id/en/population-study/ employment/152-buruh-dalam-pusaranpolitik-2014.

Warouw, Nicolaas. "Pekerja Industri Indonesia, Gerakan Buruh, Dan New Social Movement: Merajut Sebuah Kemungkinan." Jurnal Analisis Sosial 10, No. 2 (2005): 1-18.

Zuhdan, M. "Perjuangan Gerakan Buruh Tidak Sekedar Upah Melacak Perkembangan Isu Gerakan Buruh Di Indonesia Pasca Reformasi." Jurnal Ilmu Sosial Dan Ilmu Politik 17, no. 3 (2014). 